SCJR 12, no. 1 (2017): 1-3

\title{
Gerald R. McDermott, Editor The New Christian Zionism: Fresh Perspectives on Israel and the Land
}

(Downers Grove, Illinois: IVP Academic, 2016), paperback, 349 pp.

\author{
CAITLIN CARENEN \\ carenenc@easternct.edu \\ Eastern Connecticut State University, Willimantic, CT 06226
}

The New Christian Zionism: Fresh Perspectives on Israel and the Land, a collection of essays edited by Gerald R. McDermott of Beeson Divinity School, seeks to challenge the longstanding association of Christian Zionism and premillennial dispensationalism. In his introduction, McDermott offers a five part definition of this new Christian Zionism, which he uses to organize the remainder of the chapters. In the new Christian Zionism "the people and the land of Israel are central to the story of the Bible"; "the Bible is incoherent and salvation impossible apart from Israel"; the ongoing history of salvation gives Israel continued theological significance; Israel's modern state is "part of the fulfillment of biblical prophecy"; and Jews deserve their place among the nations of the earth (pp. 11-12; emphasis in original). The motivation for offering this new definition of Christian Zionism is openly political, McDermott tells the reader, and was prompted by concerns that support for Israel is "eroding all over the world" (p. 12). In particular, McDermott and the other contributors have in mind fellow Protestants holding more critical views of Israel. He argues that a careful reexamination of the New Testament reveals the centrality of the land of Israel to Jews and Christians, which has long been ignored or dismissed because of supersessionism. The new Christian Zionism, then, reflects the understanding of the significance of the land to Jews and Christians, emphasizes God's unending promise of the land to Jews, and affirms the significance of Israel in God's unfolding plan for humankind. McDermott demurs from emphasizing specific fulfillment of prophecy in modern events as a way of distancing the new Christian Zionism from premillennial dispensationalism, but prophecy and fulfillment are not absent from it.

The book is divided into four sections. McDermott is the only contributor to Part One: Theology and History. Beyond defining this "new Christian Zionism" in the introduction, McDermott seeks to dispel "modern myths" about Israel that have prevented more widespread support for Israel among Protestants (p. 26). In dispelling these "myths," however, McDermott does not offer any new arguments in favor of Christian Zionism. Rather, he echoes much of the apologetics of 
dispensational premillennial Zionism. Most problematically, McDermott skirts very complicated history in favor of a superficial interpretation of the Arab-Israeli conflict. His purpose is mainly theological, but in making a theo-political argument, he must address history far more carefully. Unfortunately, many of his references are outdated and do not reflect the most recent scholarship in a widely contested history. Next, McDermott dedicates himself to debunking supersessionism as a legitimate theology and to dispelling the idea that his new Christian Zionism in indistinguishable from premillennial dispensationalism. Interestingly, McDermott also argues that the new Christian Zionism is not new at all, and he spends considerable space tracing its history to show that "Christian Zionism is at least eighteen centuries older than dispensationalism" (p. 46).

It is clear that the purpose, the "heart," of the book, according to McDermott, is the biblical exegesis in Part Two: Theology and the Bible. Here, four scholars take a deep dive into biblical hermeneutics and exegesis, and perhaps offer this volume's best attempt to contribute new ideas to the theology of Christian Zionism. This part of the book will appeal most to theologians and seminarians as it is clearly targeted to a more theologically-advanced reader. In chapter three, Craig Blaising argues that the "New Testament is best read in continuity with the Tanak in presenting a narrative of the divine plan that includes an ethnic, national, territorial Israel" (p. 98). In chapter four, Joel Willitts argues that scholars ignore "the theological theme of the land in Matthew" and sets out to correct this since, he argues, "the people of Israel and the land of Israel persist as abiding concerns in the Gospel of Matthew" (p. 111). In chapter five, Mark S. Kinzer argues that Luke and Acts reveal an emphasis on Jerusalem as a specific geographic location and a specific future location for the restoration of Israel. The narrative is structured "geographically, with Jerusalem as its pivot" (p. 143). In the final chapter in this part, David Rudolph argues that Paul does not eliminate "particularity for Israel and the land" in his explanation of salvation (p. 194). In general, the theological studies of Christian Zionism in Part Two constitutes the volume's most original contribution.

Part Three is more overtly political, and because of an eclectic mix of topics, feels somewhat erratic. Mark Tooley begins this section with a summary history of mainline Protestantism's growing criticisms of Israel, but does not offer anything new to the existing scholarship. He fails to offer a way for evangelicals to avoid "the mainline Protestant trajectory," as he said he would. (p. 218). Rather, his chapter mainly seeks to dissuade evangelicals who might become critical of Israel. In chapter eight, Robert Benne summarizes the existing scholarship about Reinhold Niebuhr's Zionism. He says that Niebuhr's views stemmed mainly from a pragmatic need for a stable geopolitical ally in the Middle East and from his humanitarian concern for the Jews after the Second World War. Benne's original contribution to existing scholarship comes from his speculation that Niebuhr's support for Israel was religiously-based, too. Robert Nicholson in chapter nine addresses the question of the legality of Israel's existence and of Israel's behavior in the community of nations. Carefully defining both biblical justice and international law, he ultimately concludes that even if Israel's actions may be 
condemned (unfairly, he argues) by various international bodies, it has not violated either covenantal law or international law. Chapter ten, written by Shadi Khalloul, a member of Israel's minority Aramean population, offers one of the more compelling and interesting chapters. Following an overly-long historical introduction, he argues that Israel does not violate the biblical covenant in its treatment of minorities. While his argument is largely based on his own personal experiences and could not be judged objective, as a minority he does offer a unique perspective on life in modern Israel.

Finally, Part Four: Theology and the Future serves as an epilogue. While McDermott offers the final word, the other chapter by Darrell Bock would have served as an excellent concluding chapter, as he concisely summarizes the previous contributions and offers perhaps the most measured approach to dealing with Christian Zionism in the context of the Arab-Israeli conflict. In all, this volume is strongest when it focuses on theology. Its superficial treatment of modern Israeli history and the history of the Arab-Israeli conflict will not convince the skeptic. No doubt, however, the volume as a whole will empower the converted. 